\title{
Graphene oxide used for detection devices of artificial sweeteners not regulated in the food industry
}

\section{Óxido de Grafeno empleado en dispositivos de detección de edulcorantes artificiales no regulados en la industria alimenticia}

\author{
GALINDO-GONZÁLEZ, Rosario ${ }^{1,3} \dagger^{*}$, ULLOA-VAZQUEZ, Talina ${ }^{1}$, HERRASTI, Pilar ${ }^{2}$, FUENTES- \\ RAMÍREZ, Rosalba ${ }^{1}$
}

${ }^{1}$ Universidad de Guanajuato, Natural and Exact Sciences Division, Department of Chemistry Engineering.
${ }^{2}$ Autonomus University of Madrid, Department of Applied Physical Chemistry
${ }^{3}$ CONACYT cathedra in Universidad de Guanajuato, Natural and Exact Sciences Division

ID $1^{\text {st }}$ Author: Rosario, Galindo-González / ORC ID: 0000-0002-3612-1555, CVU CONACYT ID: 223987

ID $1^{\text {st }}$ Coauthor: Talina, Ulloa-Vazquez / CVU CONACYT-ID: 664273

ID $2^{\text {nd }}$ Coauthor: Pilar, Herrasti / ORC ID: 0000-0003-1067-0780

ID $3^{\text {rd }}$ Coauthor: Rosalba, Fuentes-Ramírez / ORC ID: 0000-0003-0520-3387, CVU CONACYT ID: 202669

DOI: $10.35429 /$ EJB.2019.10.6.13.18

Received: February 28, 2019; Accepted: April 20, 2019

\begin{abstract}
In this work, electrochemical sensors were developed for the detection of artificial sweeteners such as D-sorbitol and Maltitol in aqueous solutions. These compounds are classified as polyalcohols and are widely used in the food and beverage industry to replace common sugar. However, their consumption is not currently regulated, and excessive use leads to consequences in the body such as increased blood glucose levels. Graphene oxide (OG) inks were prepared, which were deposited on vitreous carbon (CV) electrodes, followed by enzymatic immobilization. The detection capacity of the biosensors was evaluated applying electrochemical techniques. The biosensor with the best levels of detection, reproducibility and durability for the analytes under study for the detection of D-Sorbitol turned out to be that measured at a working voltage of $0.86 \mathrm{~V}$ vs $\mathrm{Ag} / \mathrm{AgCl} /$ $\mathrm{KCl}(3 \mathrm{M})$, depositing $20 \mu \mathrm{L}$ of $\mathrm{OG}$ ink and using a dilution of $0.5 \mu \mathrm{L} / 100 \mu \mathrm{L}$ of (alcohol oxidase / PBS). In the case of Maltitol the best designed biosensor was worked at $1.06 \mathrm{~V}$ vs $\mathrm{Ag} / \mathrm{AgCl} / \mathrm{KCl}(3 \mathrm{M})$, depositing $20 \mu \mathrm{L}$ of $\mathrm{OG}$ ink and using a dilution of $2.0 \mu \mathrm{L} / 100 \mu \mathrm{L}$ of (alcohol oxidase / phosphate buffer).
\end{abstract}

Biosensor, Maltitol, D-sorbitol

\begin{abstract}
Resumen
Se elaboraron sensores electroquímicos para la detección de edulcorantes artificiales (D-sorbitol y Maltitol) en soluciones acuosas. Estos compuestos son polialcoholes ampliamente utilizados en la industria alimenticia y bebidas, en sustitución del azúcar común., sin embargo, su consumo no se encuentra regulado, y el uso desmedido conlleva a consecuencias en el organismo como el aumento en los niveles de glucosa en sangre. Se elaboraron tintas de óxido de grafeno (OG), que fueron depositadas sobre electrodos de carbón vítreo (CV), posteriormente se llevó a cabo la inmovilización enzimática. La capacidad de detección de los biosensores fue evaluada aplicando técnicas electroquímicas. El biosensor con los mejores niveles de detección, reproducibilidad y durabilidad para los analitos en estudio para la detección de D-Sorbitol resultó ser aquel medido en un voltaje de trabajo de $0.86 \mathrm{~V}$ vs $\mathrm{Ag} / \mathrm{AgCl} / \mathrm{KCl}(3 \mathrm{M})$, depositando $20 \mu \mathrm{L}$ de tinta de OG y utilizando una dilución de $0.5 \mu \mathrm{L} / 100 \mu \mathrm{L}$ de (alcohol oxidasa/PBS). En el caso de Maltitol el mejor biosensor diseñado se trabajó a $1.06 \mathrm{~V}$ vs $\mathrm{Ag} / \mathrm{AgCl} / \mathrm{KCl}(3 \mathrm{M})$, depositando $20 \mu \mathrm{L}$ de tinta de OG y utilizando una dilución de $2.0 \mu \mathrm{L} / 100 \mu \mathrm{L}$ de (alcohol oxidasa/Buffer de fosfatos).
\end{abstract}

Biosensor, Maltitol, D-sorbitol

Citation: GALINDO-GONZÁLEZ, Rosario, ULLOA-VAZQUEZ, Talina, HERRASTI, Pilar, FUENTES-RAMÍREZ, Rosalba. Graphene oxide used for detection devices of artificial sweeteners not regulated in the food industry. ECORFAN Journal-Bolivia. 2019. 6-10: 13-18.

\footnotetext{
* Correspondence to Author (email: mr.galindo@ugto.mx)

$\dagger$ Researcher contributing as first author
} 


\section{Introduction}

Artificial sweeteners are organic compounds that have been used to replace the use of sucrose or common sugar, preserving the sweet taste in foods, but with a lower caloric content, so they are in products recommended for People who try to lose weight and those with problems of hyperglycemia or diabetes. If the sweeteners are not used in the right portions can trigger effects on the organism as an alteration of blood glucose levels, risk of obesity, hypertension, metabolic disturbances and cardiovascular complications.

There are many sweeteners, among which we find alcohols sweetened or polyalcohols, this type of compounds are characterized because they are assimilated in a partial or slower than the sugar in the organism. Two polyalcohols were selected for this work: D-sorbitol (e-420) and Maltitol (e-965), both are long-chain branched alcohols and are commonly used in a wide variety of foods such as energy drinks, biscuits, cereals, Chewing, among many others.

Currently there are no rules or regulations that require producers to denote polyalcohols as such in the nutritional and energy labels of their food and beverages, instead, are categorized along with many other molecules such as Carbohydrates. The result of the lack of regulation of this type of compounds is that people do not know that they consume them, nor the proportion in which they do; So your intake can be a health risk factor. (Mexican Diabetes Federation, 2016).

Therefore, it is of great importance to take control of the consumption of these polyalcohols, which is achieved through monitoring within the production processes in the food industry.

One of the simplest technologies to carry out the monitoring of different chemicals is through the sensors, which carry out a rapid, economical and quantitative analysis of the analyte in question, which is why they become highly options Viable for the detection of chemicals and biomolecules in the environment, the food industry and clinical analyses (Sassolas, Blum, and Leca-Bouvier, 2012).
Among the different types of sensors known, the type of electrochemical detection are the most used because they have advantages such as low manufacturing and maintenance costs, require small volumes of samples, present sensitive Detection levels and enormous diversity for analyte detection (Alegret, Del Valle, \& Merkoci, 2004).

Depending on the type of analyte that needs to be quantified, the most appropriate type of sensor will be selected; Many of the substances that are evaluated are usually biomolecules or other biological type, in these cases the detection response can be improved in a remarkable way including in the sensor receptor biological elements such as enzymes, antibodies, proteins, among many others; The type of sensor formed by biological elements is known as biosensor. Normally enzymes are the biological elements most used for the construction of biosensors, mainly due to their selective and catalytic properties.

Electrochemical sensors have a
predominant position in the analytical instrumentation market; These are very simple technologies that do not need sophisticated measuring equipment, use very common instrumentation in laboratories such as potentiometers and Potenciostatos; The translated signal is of electrical type and easily processable by electronic methods. They are easily miniaturized devices, which allows to make measurements in small sample volumes or in areas of reduced dimensions. They present sufficient detection limits for a large majority of analytical interest samples and a wider response interval than most other types of sensors. They can be manufactured in series production techniques, with low costs and become commercialized as disposable devices without having to give them constant maintenance (Alegret, Del Valle, \& Merkoci, 2004).

In a traditional way, the sensor area has used carbon-based materials such as vitreous carbon electrodes, carbon fibers and pyrolytic graphite; However, today it has been sought to introduce carbon-based nanomaterials (Yang, Denno, \& Pyakurel, 2015); Such is the case of graphene oxide and graphene, which have been used mainly to carry out the immobilization of the bioreceptors. 
So far the most studied electrochemical biosensor based on Grafíticos materials is the one that uses the enzyme glucose oxidase for glucose detection (Lawal, 2015).

However, the presence of grafíticos materials has shown increases in sensitivity, selectivity, and reproducibility of many sensors; When it has worked on the electrochemical detection of analytes such as (Bahadir \& Sezgintürk, 2016), (Sassolas, Blum, and LecaBouvier, 2012): cholesterol, uric acid, ascorbic acid, hydrogen peroxide, methanol and glucose to name a few.

This paper presents a comparison between graphene and graphene oxide modified with the enzyme alcohol oxidase, for the elaboration of an electrochemical detection device, using synthetic samples of D-sorbitol and Maltitol, two sweeteners Widely used in the food industry, thus generating a simple, economical and effective alternative for quality control in the food industry.

\section{Methodology}

\section{Synthesis of graphene oxide}

The synthesis of graphene oxide was carried out following the technique reported by Hummer \& Offeman (Ramos-Galicia, 2014), which consisted of the following steps: In a threemouth flask placed in an ice bath, $46 \mathrm{ML}$ of sulphuric acid (karal reactive) was added. To reach a temperature of $0^{\circ} \mathrm{C}$, at this time $2 \mathrm{~g}$ of graphite (Electron Microscopy Science \#70230) were added and immediately afterwards, $6 \mathrm{~g}$ of potassium permanganate (Sigma-Aldrich reagents) was added. Once the previous components were mixed, the reaction was carried at a temperature of $35^{\circ} \mathrm{C}$ with magnetic agitation, reached this value, it was allowed to react for 2 hours. After this time the heating was removed and the flask was slowly added to $92 \mathrm{~mL}$ of distilled water, leaving the solution to react for 15 minutes with magnetic agitation.

Independently in a beaker, $270 \mathrm{ml}$ of distilled water and $10 \mathrm{ml}$ of hydrogen peroxide were added; After 15 minutes in magnetic agitation of the product obtained from the synthesis, this solution was mixed together with the hydrogen peroxide preparation. Later, the final solution was filtered until a neutral $\mathrm{PH}$ was obtained.
To this point graphite oxide has been obtained, which was allowed to dry at $65^{\circ} \mathrm{C}$ for 12 hours.

To obtain GO a solution of $(0.1 \mathrm{~g} / 10$ ML) of graphite oxide and distilled $\mathrm{H}_{2} \mathrm{O}$ was prepared respectively, the solution was soniced in an ultrasonic bath (model 1510R-MTH, at a frequency of 50-60 Hz) for a time of 4.5 hours. Finally, the solid product was separated by centrifugation, dried and ground until reaching a diameter of 75 microns (mesh \#200). Two different lots were prepared to generate enough work material.

\section{Biosensors preparation}

It begins by describing the preparation of the ink of carbon-based materials, then this ink is deposited on the surface of a vitreous carbon electrode $(\mathrm{CV})$, the next stage in the elaboration is the immobilization of the enzyme alcohol oxidase AlOx and Finally, the biosensor test is carried out in synthetic solutions of each one of the analytes under study. The modification of the CV electrode consisted of several deposits of $10 \mu \mathrm{L}$ of ink in the form of layers. During each tank a vacuum oven was used at a temperature of $60^{\circ} \mathrm{C}$, which allowed each layer to be completely dried in order to carry out the next addition. It is important to leave the modified electrode for a day so that the ink anchorage to the glassy carbon electrode is as strong as posible.

\section{Electrochemistry test}

The electrochemical characterization of the modified electrodes was used a reference electrode of $\mathrm{Ag} / \mathrm{AgCl} / \mathrm{KCl}$ (3 $\mathrm{M}$ ) and as a counterelectrode a platinum wire; The working electrode used was the developed biosensor.

\section{Results}

Figure 1 presented the Raman spectra made to the original material used that was the graphite (black line), and the samples of graphene oxide (blue line) and reduced graphene (pink line) synthesized during the investigation. In this analysis it is possible to see that the graphite has a high degree of grafítica orientation reflected in the intensity of the G-band. The defects in its structure are minimal and are manifested in the peak D1 with weak intensity. 
The ratio of area $D 1 / G$ is 0383 , which is interpretable as a material of low structural disorder.

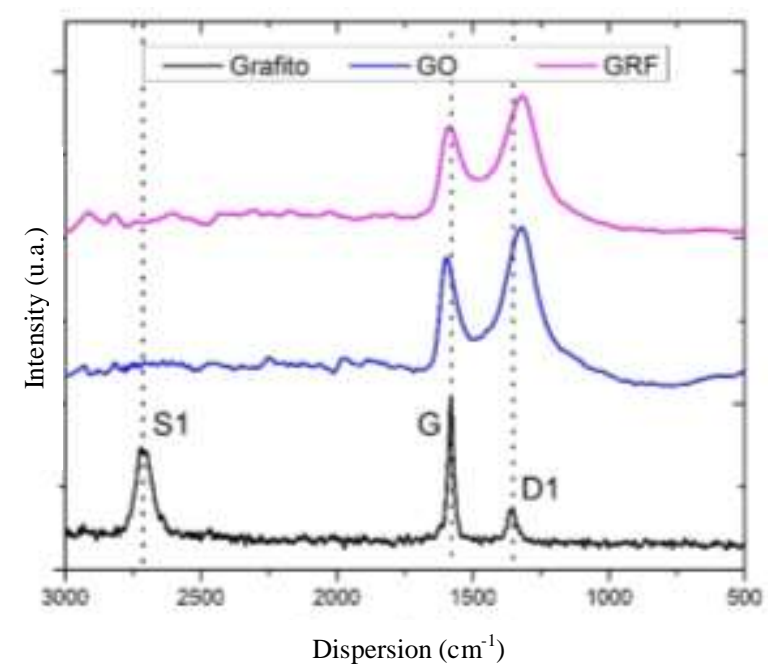

Figure 1 Raman spectra for different grafíticos materials

The G-band corresponds to the vibration within the aromatic layers in the graphite structure, its magnitude corresponds to the vibration of the C-C type SP2 hybrid link stretch. In the spectrum of the GO the G-band decreases, while the intensity of D1 increases markedly, the peaks become wider due to factors such as the presence of vacancies, defects in the structure, finite size of the net or others; They specifically represent the loss of symmetry due to the finite size of the graphite crystals or the vibration of the stretching of the hybrid links type SP2 and SP3 of the carbon atoms.

When the D1 band is intense and broad as in the case of GO, this implies that the carbonaceous material lacks ordering in its atoms (Beyssac, Goffé, \& Chopin, 2002). Mainly this band is attributed to structural defects or the presence of Heteroatoms $(\mathrm{O}, \mathrm{H}$, $\mathrm{N}$ ), resulting from the oxidation process to which the graphite was subjected. The ratio $\mathrm{D} 1 / \mathrm{G}$ for GO is 0968 because the number of defects is higher by oxidation compared to graphite.

Figure 2 corresponds to the TEM micrographs of graphene oxide, as you can see its morphology is of type flakes with at least a length of 1 micron of approximately width.

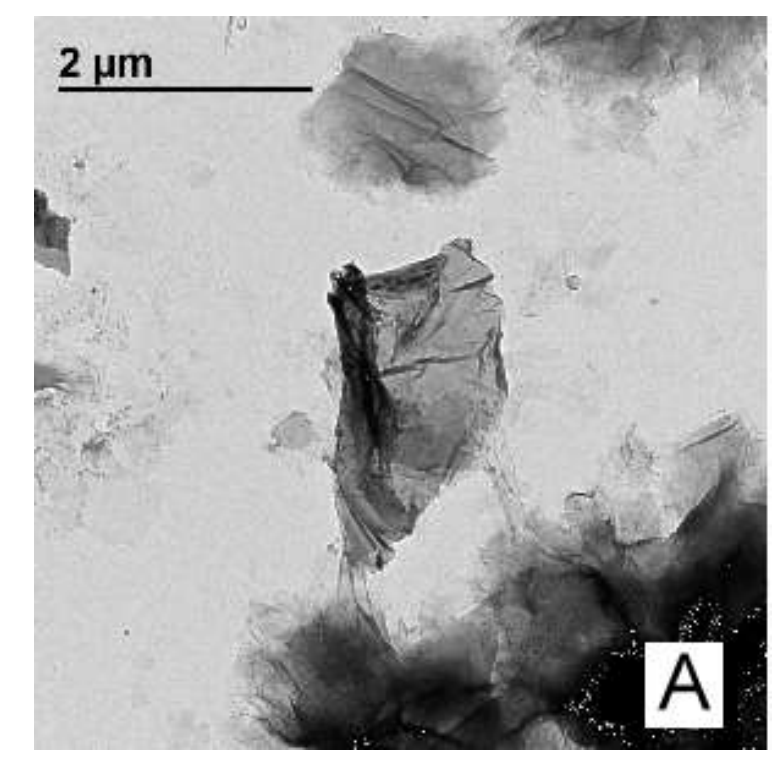

Figure 2 TEM of Grafene oxide

Figure 3 A represents an average of the cronoamperometrías obtained and $\mathrm{B}$ shows the calibration curve with the standard deviation of the values obtained for the biosensors.

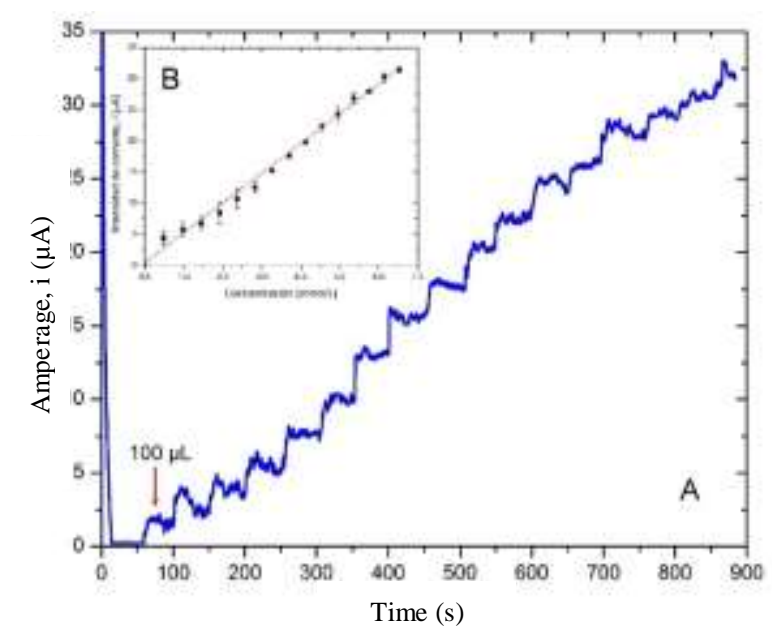

Figure 3 Results of Repetividad tests in the best conditions for sorbitol detection. A) average Cronoamperometría using a CV electrode with $20 \mu \mathrm{L}$ of TGO, $10 \mathrm{~mL}$ PBS PH $=7.4, \mathrm{E}_{\mathrm{w}}=0.864 \mathrm{~V}$ vs $\mathrm{Ag} / \mathrm{AgCl} / \mathrm{KCl}$ (3 M), (0.5 $\mu 1 \mathrm{AlOx} / 100$ MLPBS), B) linear approximation of response detection vs. Signal Current measurement

For these biosensors the following average values were obtained: sensitivity of $4.834 .83 \mu \mathrm{A} / \mathrm{mmolL}^{-1}$, minimun detection limit of $0.49 \mathrm{mmol} / \mathrm{L}$ maximun $6.52 \mathrm{mmol} / \mathrm{L}$ and linear approximation factor of 0.993 . The average cronoamperometría has a signal-tonoise ratio of 1.63 .

The Figure 4 A represents an average of the cronoamperometrías obtained B shows the calibration curve with the standard deviation of the values obtained for the biosensors 


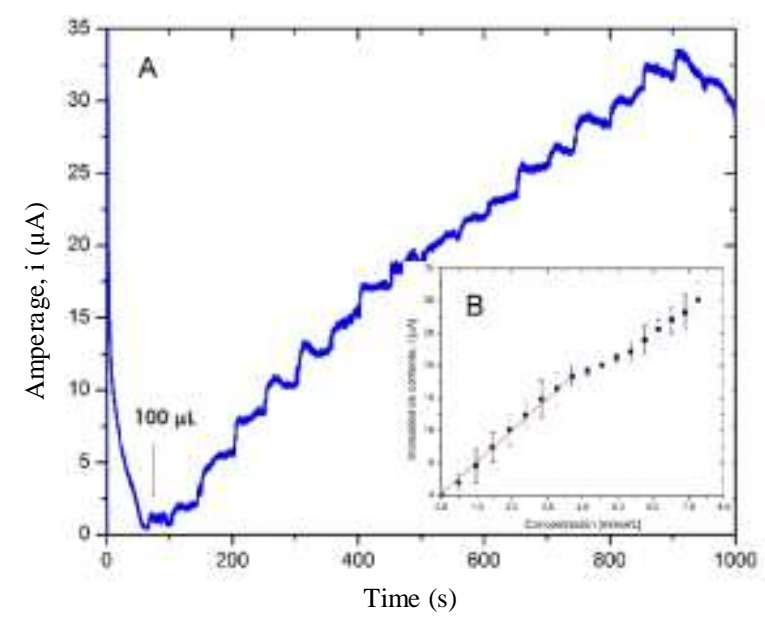

Figure 4 Results of Repetividad tests in the best conditions for maltitol detection. A) Cronoamperometry using a CV electrode $20 \mu \mathrm{L}$ de TGO, $10 \mathrm{~mL}$ PBS $\mathrm{pH}=7.4, \mathrm{E}_{\mathrm{w}}=1.064 \mathrm{~V}$ vs $\mathrm{Ag} / \mathrm{AgCl} / \mathrm{KCl}(3 \mathrm{M}),(2.0 \mu \mathrm{L}$ $\mathrm{AlOx} / 100 \mu \mathrm{L} \mathrm{PBS}), \mathrm{B})$ linear approximation of response detection vs. Signal Current measurement

For these biosensors the following average values were obtained: sensitivity of 4.92 $\mu \mathrm{A} / \mathrm{mmolL}^{-1}$, minimun detection limit of 0.49 $\mathrm{mmol} / \mathrm{L}$ and maximun $3.70 \mathrm{mmol} / \mathrm{L}$ and linear approximation factor of 0.991. The average cronoamperometría has a signal-tonoise ratio of 1.09 .

\section{Conclusions}

The GO is synthesized by means of a modified Hummer technique. In the analyses carried out to carry out the characterization, it was found that the oxidation of the material had been carried out in a satisfactory way, since they were inserted in the structure different oxygenated groups. The insertion of the oxygenated groups was also observed in the Raman spectroscopy, reflected in the variation of the width and intensity of the bands $G$ and D1 when compared with those of graphite, which was interpreted as a loss of the crystallinity of the material. The TEM microscopies allowed to visualize that the GO presents a flake structure and with an approximate size to 1 micron. The electrochemical impedance spectroscopy made it possible to conclude that the GO is a material that contributes a resistance of $200 \Omega$ once its ink is deposited and tested in the biosensor.

Given the characteristic parameters reported for each biosensor can be concluded, that the electrochemical detection of sorbitol is much better than that of maltitol, because the chemical structure of sorbitol is mostly akin to AlOx to be oxidized.
Therefore, the biosensor sheds more stable, reproducible responses with greater signal/noise ratios

\section{References}

Alegret, S., Del Valle, M., \& Merkoci, A. (2004). Sensores electroquímicos. Barcelona, España: Materials 147.

Araújo, J. R., Martel , F., \& Keating, E. (2014). Exposure to non-nutritive sweeteners during pregnancy and lactation: Impact in programming of metabolic diseases in the progeny later in life. Reproductive Toxicology, 196-201.

Azevedo, A., Prazeres, M., Cabral, J., \& Fonseca, L. (2005). Ethanol biosensors based on alcohol oxidase. Biosensors and Bioelectronics, 235-247.

Badea, M., Curulli, A., \& Palleschi, G. (2003). Oxidase enzyme immobilisation through electropolymerised films to assemble biosensors for batch and flow injection analysis. Biosensor Bioelectron, 689-698.

Bahadir, E., \& Sezgintürk, M. (2016). Applications of graphene in electrochemical sensing and biosensing. Trends in Analytical Chemistry, 1-14.

Bartlett-Johnson, M. (07 de Marzo de 2016). Universidad Latinoamericana de Ciencia y Tecnología, Costa Rica. Obtenido de Edulcorantes Naturales y Artificiales: ¿una bendición o una maldición?: http://www.ulacit.ac.cr/files/documentosULAC IT/Constant/MadisonInvestigacionEdulcorantes -QuimicaOrganica.pdf

Beyssac, O., Goffé, B., \& Chopin, C. (2002). Cernat, A., Tertis, M., \& Sandulescu, R. (2015). Electrochemical sensors based on carbon nanomaterials foracetaminophen detection: A review. Analytica Chimica Acta, 16-28.

Chunmei, M., Zhen, S., Changbao, C., \& Zhang, L. (2014). Simultaneos separation and determination of fructose, sorbitol, glucose and sucrose in fruits by HPLC-ELSD. Food Chemistry, 784-788. 
Cökeliler , D., \& Mutlu, M. (2002). Performance of amperometric alcohol electrodes prepared by plasma polymerization technique. Anal. Chim. Acta, 217-223.

Company, T. G. (02 de Marzo de 2016). Graphene \& Grafeno, The Graphene Company. Obtenido de Óxido de grafeno: http://www.oxidodegrafeno.com/es/

Wang, J., Liu, J., \& Cepra, G. (1997). Thermal stabilization of enzymes immobilized within carbon paste electrodes. Anal. Chem, 31243127.

Wen, S., Slining, M., \& Popkin, B. (2012). Use of caloric and noncaloric sweeteners in US consumer packaged foods, 2005-2009. eat rigth.

Wen, S., Slining, M., \& Popkin, B. (2012). Use of Caloric and Noncaloric Sweeteners in US consumer Packaged Foods, 2005-2009. Eat right, 1828-1834.

Wikipedia La Enciclopedia libre. (30 de Marzo de 2016). Obtenido de Conductividad eléctrica: https://es.wikipedia.org/wiki/Conductividad_el $\% \mathrm{C} 3 \%$ A9ctrica

Yang, C., Denno, M., \& Pyakurel, P. (2015). Recent trends in carbon nanomaterial-based electrochemical sensors for biomolecules: A review. Analytica Chimica Acta, 17-37.

Zhang, \& Hoshino. (2014). Electrical Transducers. Electrochemical Sensors and Semiconductor Molecular Sensors. En Zhang, \& Hoshino, Molecular Sensors and Nanodevices (págs. 169-225). Elsevier Inc.

Zygler, A., Wasik, A., \& Namiésnik, J. (2009). Analytical methodologies for determination of artificial sweeteners in foodstuffs. Trends in Analytical Chemistry. 